KARINA LEKSY

ORCID 0000-0001-5907-7836

Uniwersytet Ślaski

w Katowicach

\title{
THE SIGNIFICANCE OF THE PARTICIPATORY APPROACH IN HEALTH PROMOTION AND CANCER PREVENTION ${ }^{1}$
}

\begin{abstract}
AвsтRAct. Leksy Karina, The Significance of the Participatory Approach in Health Promotion and Cancer Prevention [Znaczenie podejścia partycypacyjnego w promocji zdrowia i profilaktyce nowotworowej]. Studia Edukacyjne nr 56, 2020, Poznań 2020, pp. 309-321. Adam Mickiewicz University Press. ISSN 1233-6688. DOI: $10.14746 /$ se.2020.56.17
\end{abstract}

The global spread of cancer makes every preventive action aiming at stopping the increase in number of cases and deaths related to cancer extremely important. Preventive actions may be especially effective in diseases etiologically related to lifestyles, including above all eating habits and level of physical activity. It is worth implementing them in compliance with the participatory approach, which constitutes a key component of health promotion and health education. The aim of this article is to present the reasons for and the need to implement prevention based on the idea of participation. This is justified by the results of the research conducted as part of a grant sponsored by Polska Liga Walki z Rakiem [Polish Cancer League] (“Onkogranty II” contest), entitled Promotion of healthy eating habits and physical activity in primary schools throughout the city of Bytom - a diagnosis of educational needs in the context of planning effective actions in primary cancer prevention. It seems that involving students in the process of identifying needs, determining priorities, planning and evaluating these actions is currently one of the most effective ways of developing awareness of cancer prevention.

Key words: cancer, participatory approach, cancer prevention, health promotion

\section{Cancer - a current problem of global public health}

Cancer is currently one of the most critical issues of global public health. According to World Health Organization, it is the main cause of diseases

${ }^{1}$ This article was based on the research conducted as part of a grant entitled "Promotion of healthy eating habits and physical activity in primary schools throughout the city of Bytom - a diagnosis of educational needs in the context of planning effective actions in primary cancer prevention", sponsored by Polska Liga Walki z Rakiem [The Polish Cancer League]. The grant was carried out by dr hab. Katarzyna Borzucka-Sitkiewicz and dr Karina Leksy from the Institute of Pedagogy of the University of Silesia in Katowice. 
and deaths. In 2012, nearly 14 million new cancer cases and 8 million cancer deaths were recorded. ${ }^{2}$ It is expected that by 2025 , the global burden of cancer will exceed 20 million of new cases annually. ${ }^{3}$ Cancers also constitute a great problem in Poland where each year ca. 160 thousand new cases are recorded and it is expected that this number may increase up to 185 thousand over the next 10 years which will make cancer the main cause of deaths in Poland. ${ }^{4}$

Cancers are caused by many factors and one of them is lifestyle and its elements such as: eating habits, level of physical activity, smoking, overconsumption of alcohol, too much sun exposure, and avoiding preventive examinations. At the same time, it is worth noticing that in respect of residents of European countries, it was stated that "the risk of developing cancer among people who lead a healthy lifestyle in line with recommendations for cancer prevention is about $18 \%$ lower than among those whose lifestyle and body weight do not comply with these recommendations" ${ }^{5}$ According to World Cancer Report 2014, too much fatty tissue involves a higher risk of developing esophageal, colorectal, endometrial, renal cancer, and breast cancer after menopause. It proves the necessity of controlling body weight and changing old habits for health-oriented ones. Regular physical activity is also significant since it lowers the risk of developing many types of cancer (including colorectal and breast cancer) mainly because of its effect on body weight. Moreover, among factors responsible for weight gain it is recommended to reduce the consumption of high sugar drinks, red meat (especially processed meat) which has significance in colorectal cancer. It is worth adding that although according to the current researchers' knowledge, diets rich in fruits, vegetables and wholegrain products do not seem to offer as high protection as it was thought before, they are still recommended not only for prevention of diabetes and cardiovascular diseases, but also because of the possibility of lower risk of developing cancer. ${ }^{6}$

${ }^{2}$ D. Forman, J. Ferlay, The global and regional burden of cancer, [In:] World Cancer Report 2014, Ed. B.W. Stewart, C.P. Wild, Lyon 2014, p. 16, http:/ / publications.iarc.fr/Non-Series-Publications/World-Cancer-Reports/World-Cancer-Report-2014 [date of access: 07-02-2020].

${ }^{3}$ F. Bray, Transitions in human development and the global cancer burden, [In:] World Cancer Report 2014, p. 54.

${ }^{4}$ Strategia Walki z Rakiem w Polsce 2015-2024 [Strategy Against Cancer in Poland 2015-2024], 10 June 2014 (updated in May 2017). http://ligawalkizrakiem.pl/images/content/Strategia-Walki-z-Rakiem-w-Polsce/Strategia_wersja_2017.pdf [date of access: 07-02-2020].

${ }^{5}$ Europejski Kodeks Walki z Rakiem, Dieta. [The European Code Against Cancer: Diet.] https://cancer-code-europe-iarc.fr/index.php/pl/12-sposobow/dieta; [date of access: 23-122018].

${ }^{6}$ W.C. Willett, T. Key, I. Romieu, Diet, obesity, and physical activity, [In:] World Cancer Report 2014, p. 124. 
It seems that raising public awareness concerning the significance of lifestyle, including the necessity of undergoing preventive examinations, is today one of the greatest challenges in the context of cancer prevention. "Public understanding of the significance of cancer risk factors, and consequently establishing competence in terms of health, is one the fundamental steps to lowering the risk of developing selected illnesses". Sadly, the level of knowledge on cancer risk factors as well as actions and behaviours which may lower the possibility of developing cancer is still insufficient among the Polish society. ${ }^{7}$

\section{Student participation in actions of health promotion within school environment}

Undoubtedly, in respect of cancer, educational and preventive actions implemented both locally and nationwide are urgent and necessary. As part of educational actions, wide promotion and popularisation of recommendations of the European Code Against Cancer among children, youth, teachers, and educators as well as cooperation with non-governmental organizations regarding education of local communities about risk factors of malignant cancer are especially recommended. ${ }^{8}$ The participatory approach that currently constitutes a key component of health promotion may be one of the methods. It is perceived as a remarkably important element of every strategy aiming at achieving the objectives of health promotion including, above all, strengthening not only individual and social health, but also with regard to social determinants of health and lifestyle of an individual. ${ }^{9}$ The notion of participation ${ }^{10}$ within theory and practice of health education in school dates back to 1970s when this idea was widely discussed and introduced in Western Europe. It was intensified by the Convention on the Rights of the Child of 1989 as a result of which the issue of active participation of children and youth in matters concerning life in society and education, including health and environmental education. ${ }^{11}$ Altho-

7 Strategia Walki z Rakiem w Polsce 2015-2024.

${ }^{8}$ Ibidem.

${ }^{9}$ Ibidem.

10 According to Merriam-Webster Dictionary (Merriam-Webster. 2014. Merriam-Webster Online Dictionary; accessed March 4, 2014 http://www.merriam-webster.com/) there are two basic meanings of the notion of participation. The first of them refers to "taking part in something", "being present", the second to "having a part or share in something" which may be related to such notions as "intensification" and "ownership" and refer to the sense of being taken seriously and having influence. After: J.A. Lysgaard, V. Simovska, The significance of 'participation' as an educational ideal in education for sustainable development and health education in schools, Environmental Education Research, 2015, 14 April, p. 616.

${ }_{11}$ B. Levy, M. Zint, Toward Fostering Environmental Political Participation: Framing an Agenda for Environmental Education Research, Environmental Education Research, 2013, 19(5), p. 553-576. After: J.A. Lysgaard, V. Simovska, The significance of 'participation', p. 613-630. 
ugh there is no unambiguous definition of participation, there is agreement that active involvement of target audience is crucial in the context of the effectiveness of health promotion strategy. Participation of persons in making decisions concerning planning and implementing health promotion programmes is very valuable from the perspective of the possibility of creating the impact, its effectiveness visible in health improvement and growth of health competence and involvement in health issues. ${ }^{12}$ In respect of education, the notion of participation is directly related to diverse understanding of interactivity as an important strategy aiming at improving students' motivation and their commitment to various activities in school and/or within the local community. ${ }^{13}$ Participation may also be understood as the "voice of the youth" consolidated in the discussion on what adolescents have to say. ${ }^{14}$

From the perspective of education, the concept of participation originally referred to three ways of understanding benefits resulting from engaging in educational activities:

- participation as children's right to express their point of view, to be listened to and taken seriously (this argument depends on the relation between school and community creating the possibility of organising the learning process in a democratic and integrating way);

- participation as something beneficial for children's social and psychological development and thus, something contributing to better educational achievements;

- participation as something beneficial to the whole society since it potentially strengthens the sense of democratic influence and understanding of balanced development and health. ${ }^{15}$

The significance of the participatory approach was, among others, emphasised in the Galway Consensus Conference in $2009{ }^{16}$ where "including people into the process of identification of needs, determining priorities, and planning and evaluating practical actions" was acknowledged as one of the fundamental values and principles in health education and health

12 U. Griebler et al., Effects of student participation in school health promotion: a systematic review, Health Promotion International, 2017, 32, 2, p. 195-206, http://publications.iarc.fr/NonSeries-Publications/World-Cancer-Reports/World-Cancer-Report-2014 [date of access: 07-022020].

${ }^{3}$ V. Simovska, The Changing Meaning of Participation in School Based Health Education and Health Promotion: The Participants' Voices, "Health Education Research" 2007, 22 (6), pp. 846-879.

14 U. Griebler et al., Effects of student participation in school health promotion, p. 198.

15 J.A. Lysgaard, V. Simovska, The significance of 'participation', p. 616-617.

16 J.P. Allegrante, M.M. Barry, C.O. Airhihenbuwa et al., Towards international collaboration on credentialing in health promotion and health education: The Galway Consensus Conference, Health Education and Behaviour, 2009, 36(3), p. 427-436. 
promotion. ${ }^{17}$ This stand found its justification in the research conducted by U. Griebler, D. Rojatz, V. Simovska, and R. Forster. These researchers reviewed the results of research and publications on the effectiveness of students' commitment to activities within the scope of students' involvement in actions concerning planning, implementing and/or evaluating actions related to health promotion in schools. On the basis of their analysis, they indicated positive effects of the participatory approach at three levels:

- at an individual level - for students: increase in satisfaction, motivation, knowledge, skills, and competence, self-development, closer attention to health issues;

- at an institutional level - for schools as organizations: positive impact on school atmosphere, principles, policy, and infrastructure;

- at a social level - improvement of cooperation and social relations in school (relations between peers, students, and between students and adults).

In the publications under analysis, positive impact of students' participation referring to other people (parents, teachers) in relation to interventional programmes and local community within school was indicated less frequently. It is worth emphasising that almost all publications under analysis indicated positive impact at an individual level, which according to the researchers makes up the so-called "action competence". Literature in the field of health promotion and health education defines this term as an individual ability to introduce changes towards health-oriented behaviours and/or deeper sensitivity to factors affecting health in daily life. Consequently, active participation of students in making decisions on health promotion is really essential and valuable from the perspective of benefits both at an individual (students) and social (schools) level. ${ }^{18}$

\section{The purpose of the analysis and an outline of the own research}

The purpose of this article is to present the significance and, apparently, the need of introducing the participatory approach during the implementation of prevention and health promotion programmes in schools. Taking into account the above quoted analyses proving the effectiveness of such actions manifesting themselves in an increase in students' knowledge, health awareness, and positive changes in behaviours, this opportunity seems to

${ }_{17}$ B. Woynarowska: Nowe koncepcje $i$ strategie w edukacji zdrowotnej w Europie [New concepts and strategies in health education in Europe]. [In:] Pedagogika zdrowia w teorii i praktyce [Pedagogy of health in theory and practice], Eds. B. Zawadzka, T. Łączka, Kielce 2017, p. 39.

${ }^{18}$ U. Griebler et al., Effects of student participation in school health promotion, p. 202-204. 
be justified especially with regard to prevention of cancer which, as it was mentioned in the beginning, spreads widely and basically, that is why today almost everybody is at risk of developing cancer. At the same time, the research conducted as part of the grant entitled Promotion of healthy eating habits and physical activity in primary schools throughout the city of Bytom - a diagnosis of educational needs in the context of planning effective actions in primary cancer prevention, sponsored by Polska Liga Walki z Rakiem [the Polish Cancer League] ("Onkogranty II") ${ }^{19}$ showed that students' knowledge on the possibilities of lowering the risk of developing cancer through a change of lifestyle, especially in the context of types of cancer that depend ${ }^{20}$ on it, is little. ${ }^{21}$ At the same time, one of the purposes of the conducted research was to determine students' needs concerning effective ways of transmitting knowledge and shaping skills in lifestyle oriented towards health and cancer prevention as well as the areas that are perceived by them as deficient in respect of the knowledge and skills they have. It was important to receive students' feedback on the most essential contents and actions that schools should perform in respect of healthy eating habits and increase in physical activity. Therefore, one of the research questions read as follows: What are, in students' opinion, the conditions of effective performance of actions concerning promotion of healthy eating habits and physical activity and what contents are perceived by students as deficient in the context of cancer prevention? In order to answer those questions, in September and October 2018 focus group interviews were conducted with students in schools located in 4 different districts of Bytom which are characterised by different social and cultural capital. Even though the obtained results refer to the students and schools taking part in the research, they may be an important indication for taking more effective actions in cancer prevention on a broader scale in the future.

${ }^{19}$ Research issues formulated for the purposes of the project were consistent with "Strategy Against Cancer in Poland 2015-2024", and more specifically, with its purpose no. 10: Promotion of healthy eating habits and physical activity, as well as with the first operational objective of the "National Health Programme for the years 2016-2020", that is: Improvement of eating habits, state of nutrition, and physical activity of the society. Performed actions were oriented towards increasing the interest in primary prevention focused on the urgent need to stimulate social awareness of oncological health.

${ }^{20}$ These are: colorectal cancer, breast cancer, endometrial cancer, esophageal cancer, stomach cancer, oral cancer, liver cancer, gallbladder cancer, and renal cancer (Cf. National Cancer Registry: Diet. http:/ / onkologia.org.pl/dieta; [date of access: 23-12-2020]; National Cancer Registry: Physical activity. http:/ / onkologia.org.pl/aktywność-fizyczna/; [date of access: 23-122020].

${ }^{21}$ Cf. K. Leksy, Świadomość zdrowotna uczniów w kontekście zapobiegania chorobom nowotworowym [Students' health awareness in the context of cancer prevention], Pedagogika Społeczna [Social Pedagogy], 2019, 2, p. 87-99. 


\section{The results of the own research}

Before presenting the results of the above described fragment of the research, it should be mentioned that on the basis of a survey $(\mathrm{N}=388$ students aged 14), low level of knowledge and awareness of the youth of the relation between healthy eating habits and physical activity and cancer prevention was noticed. At the same time, taking into account the focus group interviews with students which concerned two essential elements of lifestyle, that is eating habits and physical activity, the analysis of their utterances and written works ${ }^{22}$ showed that prevention and educational programmes in school and performed actions concerning improvement of eating habits and increase in physical activity did not sufficiently motivate students to changes in that respect. What is important, the students frequently mentioned their parents as those who encouraged them to improve their eating habits and increase their physical activity. According to the respondents, mass media had also significant influence, especially the Internet, bloggers, and "YouTubers" popular among teenagers. In the context of the most important contents and actions that should be carried out in school, the students indicated, above all, actions such as: distribution of fruits, vegetables, and milk; field trips oriented towards healthy lifestyle; educational meetings and film projections on the theme of health; information raising awareness of unhealthy eating habits and benefits resulting from rational nutrition. The respondents also underlined the significance of media, including theme blogs and promotion of healthy diet in mass media. On the other hand, in the context of contents and actions that are deficient in the field of promotion of healthy diet done in school, the students pointed out lack of nutrition workshops, sessions with well-known and renowned experts in this field who would encourage and motivate the

${ }^{22}$ As first, the students had to answer the questions aiming at assessing current actions in school concerning promotion of healthy eating habits and physical activity and their relation with cancer prevention. Then, using the "draw and write" technique and as part of individual work, they had to indicate whether and how they changed their eating habits and physical activity under the influence of prevention and education classes introduced in school. The next task concerned determining steps which should be taken in order to improve the effectiveness of prevention and education effects in school, the task involved the techniques of "Brainstorming" and "the Priority Pyramid". The students were divided into 4 groups and each group answered one of the following questions: 1) What contents and actions are, in your opinion, the most important in promotion of healthy eating habits? 2) What contents and actions are, in your opinion, deficient in promotion of healthy eating habits implemented in school? 3) What contents and actions are, in your opinion, the most important in promotion of physical activity? 4) What contents and actions are, in your opinion, deficient in promotion of physical activity implemented in school? The last task performed by the students concerned presenting, by the use of the technique of "Mind mapping", their suggestions and ideas of how to conduct effective classes on promotion of healthy eating habits and increase in physical activity. 
youth to eat healthy. The respondents also mentioned the need to provide practical solutions concerning healthy diet in school (for example, access to drinking water dispensers). It is worth noticing that the youth hardly indicated any specific content which they lack in current preventive and educational actions in school.

Diagnosis of students' opinion about the most important contents and actions in promotion of physical activity was raised during the focus group interviews. According to the respondents, mass media have the greatest influence and through them it is possible to promote physical activity (sports campaigns and publicity; influential people encouraging to take up sports). The students also considered promotion of awareness of the health effects produced by lack of physical activity to be very important. On the other hand, in the context of promotion of physical activity, the respondents cited as deficient the following: lack of knowledge of the effects of low level of physical activity, lack of motivation and no examples to follow provided by their teachers. Most frequently the respondents indicated practical solutions, such as swimming, sports competitions, field activities, and making Physical Education classes more diverse. The interviews also show that the students often lack motivation due to Physical Education classes where boys and girls are integrated, lack of sports equipment or school team. In reference to the aspect under analysis, once again the students mainly indicated actions and practical solutions rather than specific contents which, according to them, could increase their motivation to undertaking regular physical activity.

The students were also asked how to conduct classes on promotion of healthy eating habits and physical activity to make them as effective as possible. Their answers were grouped into three categories referring to specific spheres of daily life: school, local community, and media. It is worth noticing that many of the students' suggestions concerning school activities referred to traditional approach to teaching (talks, presentations, lectures, transmission of information). Thus, the students cited activities which are well-known to them, yet not very effective (both in the context of raising awareness and changing habits). However, there were some valuable suggestions which could be used as part of the participatory approach, for example: introduction of recreational breaks; more sports events and competitions; taking into consideration students' opinions and suggestions; stronger motivation provided by teachers; classes on cooking and preparing healthy meals; talks with experts/famous people involved in healthy eating and physical activity. According to the students, activities that should be undertaken within local community should include: discounts on healthy food products; increase in prices for fast-food and other products harmful to health; meetings with dieticians and sportspeople; local social actions/competitions/contests related 
to healthy lifestyle. Currently, mass media, especially the Internet, are of great importance to young people. Therefore, among initiatives that are undertaken in mass media, they proposed: social campaigns; interviews with sportspeople, advertisements oriented to healthy eating; mobile applications about healthy lifestyle; thematic discussions on Internet forums; "valuable" Youtube channels; theme blogs.

To sum up, the students had many ideas of how to perform actions which would contribute to an improvement in physical activity and healthy eating. However, what is especially important is the fact that lack of motivation to introduce health-oriented changes frequently cropped up in the students' statements.

\section{Summary and Conclusions}

Focus group interviews revealed several conclusions. Above all, if the students decided to introduce some positive changes (in respect of healthy eating and physical activity), they were most frequently motivated by the desire to improve their physical appearance, to be "fit", and to lose weight. What may be a bit surprising is the fact that many students mentioned their parents as those who motivated them to introduce healthy principles to their daily life which may prove at the same time that health awareness of parents is beginning to change. ${ }^{23}$ Young people are enormously influenced by mass media, especially by the Internet including popular bloggers and YouTubers. Sadly, according to majority of the students, school did not contribute at all or slightly contributed to changes oriented towards healthy eating and higher physical activity level. In reference to the contents about promotion of healthy eating and the significance of physical activity for health which were introduced in school, the students demonstrated little knowledge. "We heard something" was the dominating statement, but the students were unable to specify what they heard and why. Moreover, the students noticed the relation between healthy eating and physical activity and general health, some of them gave examples of diseases (mainly obesity, and cardiovascular diseases) resulting from behaviours harmful to health, however, they did not notice this relation in reference to cancer prevention. It probably results from the lack of contents concerning cancer prevention included in preventive and educational school programmes and in most of the outside programmes used by the schools included in the research (except for "The European Code Against Cancer" programme). Additionally, series

${ }^{23}$ However, it was more visible in the schools located in the districts with higher social and cultural capital. 
of initiatives undertaken by the schools were just temporary and concerned various issues and matters. Thus, the knowledge concerning cancer prevention and justifying the significance of healthy eating and daily physical activity which is transmitted to students cannot be described as systematized, consistent, and spiral. It seems that all that is lacking is the real participation and involvement of students in the matter and actions under discussion. In other words, all that is lacking is the presence and participation of students. It results in deficiencies in health awareness and appropriateness of undertaking various health-oriented actions. Meanwhile, the issue under discussion constitutes an element that should be included by schools in planning preventive and educational actions, all the more that in the Strategy Against Cancer in Poland 2015-2024 it is claimed that: "it is important to introduce educational programmes on healthy eating in local communities which would engage various circles (among others, doctors, social workers, local authorities, non-governmental organizations, churches, schools, food producers, media) in multisectoral and long-term cooperation. Educational actions directed to various target groups (children, parents, pregnant women, the elderly) should be appropriately adjusted and diversified" ${ }^{24}$ It seems that programmes based on the participatory approach, that is the active participation of children and youth in actions aiming at improving their health: The IVAC Approach (Investigation - Vision - Action - Change), will be more diversified and will exert more influence on students and the whole school community. ${ }^{25}$ This approach should be the starting point for planning and introducing actions and participation of students in health promotion and health education. ${ }^{26}$ Additionally, this idea supports the development of subjectivity and competence for action or ability to make changes concerning health. Development of abilities to act and manage changes of children and youth should be the chief purpose of work as part of the participatory approach and thus, their knowledge and understanding of a problem should be oriented towards action and solution. Using this principle as a starting point has an enormous significance for the knowledge gained by the youth which will determine future planning, implementing, and assessing their participation, undertaken actions, and introduced changes. The authors of the approach under discussion claim that interdisciplinary knowledge which takes into account the relations between health, people, culture, and

${ }^{24}$ Strategia Walki z Rakiem w Polsce 2015-2024.

${ }^{25}$ V. Simovska, B.B. Jensen, Conceptualizing participation - the health of children and young people. A report prepared for the European Commission Conference on Youth Health, Brussels, Belgium, 9-10 July 2009, WHO, Regional Office for Europe, Denmark.

${ }^{26}$ However, the authors of this approach underline that it can be also used in reference to other contexts which aim at involving young people in their actions. 
society is the most valuable element. ${ }^{27}$ Thus, the idea of participation may be also used in reference to cancer prevention programmes.

Undoubtedly, carrying out preventive actions based on participation constitutes a great challenge not only for students who take part in such projects, but also for teachers and school coordinators. For teachers, this task may be extremely difficult and demanding since participation is not a traditional and commonly adopted approach to education. Therefore, they need not only thorough preparation for carrying out health promotion in schools, but also support from school principals and other people involved in such actions. It is essential for teachers to take part in planning projects and to have the possibility of receiving help in sensitive areas. ${ }^{28}$ Moreover, it is worth remembering that one of the factors that support health promotion in school (also in the participatory approach) is investing in development of teachers' competencies, improvement of their personal and social skills ${ }^{29}$ so that they become genuine guides in discovering the significance of health and health care.

Taking into account how important effective prevention, especially in reference to cancer, and awareness of risk and preventive factors are, it is worth making efforts to adopt and develop the participatory approach in the hope of lowering cancer incidence rates and especially those related to lifestyle. It should be underlined that the extensive research conducted over that last few decades provided important evidence on the significance of prevention of cancer and other chronic diseases and that is why the World Health Organization undertakes series of actions for this purpose. For example, The WHO Global Strategy for Prevention and Control of Noncommunicable Diseases refers to four risk factors related to lifestyle, namely smoking, unhealthy diet, lack of physical activity, and overconsumption of alcohol. The WHO Global Strategy on Diet, Physical Activity, and Health includes extensive data based on research that underlines the significance of diet change and higher level of physical activity in general population. The emphasis is put on production, availability, and promotion of healthy food products. Moreover, The WHO Global Strategy to Reduce the Harmful Use of Alcohol describes initiatives aiming at reducing the use of alcohol with the emphasis on policy related to production and distribution of alcohol. Each of the programme emphasises the enormous potential

${ }^{27}$ V. Simovska, B.B. Jensen, Conceptualizing participation - the health of children and young people, p. 25.

${ }^{28}$ Cf. V. Simovska, Case Study of a Participatory Health Promotion Intervention in School, Democracy \& Education, 2012, 20, 1, p. 8; J.A. Lysgaard, V. Simovska, The significance of 'participation', p. 15.

${ }_{29}$ B. Woynarowska, Edukacja zdrowotna i promocja zdrowia w szkole [Health education and promotion in school], [In:] Edukacja zdrowotna. Podstawy teoretyczne. Metodyka. Praktyka [Health Education. Theoretical fundamentals. Teaching methods. Practice], Ed. B. Woynarowska, Warszawa 2017, p. 223. 
of preventive actions carried out in general population and based on health promotion and policy oriented to specific risk factors related to lifestyle for the purposes of preventing chronic diseases. ${ }^{30}$ However, apart from undoubtedly important and necessary global actions, grassroots and local initiatives introduced in the living environment of people are also needed. Taking into account the context of this article, these initiatives will primarily include actions carried out in schools with active and real participation of students and other people from the local community.

\section{BIBLIOGRAPHY}

Allegrante J.P., Barry M.M., Airhihenbuwa C.O. et al., Towards international collaboration on credentialing in health promotion and health education: The Galway Consensus Conference, Health Education and Behaviour, 2009, 36(3).

Bray F., Transitions in human development and the global cancer burden, [In:] World Cancer Report 2014, Ed. B.W. Stewart, C.P. Wild, WHO, Lyon 2014. http://publications.iarc. fr/Non-series-Publications/World-Cancer-Reports/World-Cancer-Report-2014 [date of access: 07-02-2020].

Europejski Kodeks Walki z Rakiem, Dieta. [The European Code Against Cancer: Diet.] https://cancer-code-europe-iarc.fr/index.php/pl/12-sposobow/dieta [date of access: 23-12-2018].

Forman D., Ferlay J., The global and regional burden of cancer, [In:] World Cancer Report 2014, Ed. B.W. Stewart, C.P. Wild, WHO, Lyon 2014.

Griebler U., Rojatz D., Simovska V., Forster R., Effects of student participation in school health promotion: a systematic review, Health Promotion International, 2017, 32, 2. http:/ / publications.iarc.fr/Non-Series-Publications/World-Cancer-Reports/World-Cancer-Report-2014 [date of access: 07-02-2020].

http://ligawalkizrakiem.pl/images/content/Strategia-Walki-z-Rakiem-w Polsce/Strategia_wersja_2017.pdf [date of access: 07-02-2020].

Krajowy Rejestr Nowotworów, Aktywność fizyczna [National Cancer Registry: Physical activity]. http:/ / onkologia.org.pl/aktywność-fizyczna/ [date of access: 23-12-2020].

Krajowy Rejestr Nowotworów: Dieta [National Cancer Registry: Diet]. http:/ /onkologia. org.pl/dieta [date of access: 23-12-2020].

Leksy K., Świadomość zdrowotna uczniów w kontekście zapobiegania chorobom nowotworowym [Students' health awareness in the context of cancer prevention], Pedagogika Społeczna [Social Pedagogy], 2019, 2.

Levy B., Zint M., Toward Fostering Environmental Political Participation: Framing an Agenda for Environmental Education Research, Environmental Education Research, 2013, 19(5).

Lysgaard J.A., Simovska V., The significance of 'participation' as an educational ideal in education for sustainable development and health education in schools, Environmental Education Research, 2015, 14 April.

Merriam-Webster Online Dictionary; http:/ / merriam-webster.com/

${ }^{30}$ P. Puska, Prevention strategies common to noncommunicable diseases, [In:] World Cancer Report 2014. 
Puska P., Prevention strategies common to noncommunicable diseases, [In:] World Cancer Report 2014, Ed. B.W. Stewart, C.P. Wild, WHO, Lyon 2014, p. 298. http:// publications.iarc. fr/Non-Series-Publications/World-Cancer-Reports/World-Cancer_Report-2014[date of access: 07-02-2020].

Simovska V., Case Study of a Participatory Health Promotion Intervention in School, Democracy \& Education, 2012, 20, 1.

Simovska V., Jensen B.B., Conceptualizing participation - the health of children and young people, A report prepared for the European Commission Conference on Youth Health, Brussels, Belgium, 9-10 July 2009, WHO, Regional Office for Europe, Denmark.

Strategia Walki z Rakiem w Polsce 2015-2024 [Strategy Against Cancer in Poland 2015-2024], 10 June 2014 (updated in May 2017).

Willett W.C., Key T., Romieu I., Diet, obesity, and physical activity, [In:] B.W. Stewart, C.P. Wild, World Cancer Report 2014, WHO, Lyon 2014. http://publications.iarc.fr/ Non-Series-Publications/World-Cancer-Reports/World-Cancer-Report-2014 [date of access: 07-02-2020].

Woynarowska B., Edukacja zdrowotna i promocja zdrowia w szkole [Health education and promotion in school], [In:] Edukacja zdrowotna. Podstawy teoretyczne. Metodyka. Praktyka [Health Education. Theoretical fundamentals. Teaching methods. Practice], Ed. B. Woynarowska, Wydawnictwo Naukowe PWN, Warszawa 2017.

Woynarowska B., Nowe koncepcje $i$ strategie w edukacji zdrowotnej w Europie [New concepts and strategies in health education in Europe], [In:] Pedagogika zdrowia w teorii i praktyce [Pedagogy of health in theory and practice], Eds. B. Zawadzka, T. Łączka, Wydawnictwo Uniwersytetu Jana Kochanowskiego, Kielce 2017. 